\title{
Diretrizes para Colaboradores
}

Revista @rquivo Brasileiro de Educação

rtigos - A Revista @rquivo Brasileiro de Educação publica originais
inéditos resultantes de pesquisa acadêmica, ensaios temáticos e
resumos expandidos de dissertações e teses. Conta com uma seção de Resenhas e outros produtos culturais de interesse educacional. A revista terá números multitemáticos. Contudo, poderá publicar números temáticos, conforme definidos pelo Conselho Editorial.

Deverá ser observada a NBR 6023:2002 da Associação Brasileira de Normas Técnicas, no preparo do original. 